\section{Heavy metal bioaccumulation in commercial Lethrinidae fish species in Mauritius}

\author{
Bhanoo Saulick, ${ }^{1}$ \\ Vishwakalyan Bhoyroo, ${ }^{1}$ \\ Nadeem Nazurally, ${ }^{2}$ \\ Bhanooduth Lalljee ${ }^{1}$
}

${ }^{1}$ Department of Food Sciences, Faculty of Agriculture, University of Mauritius, Reduit; ${ }^{2}$ Faculty of Ocean Sciences, University of Mauritius, Reduit, Mauritius

\begin{abstract}
Concentrations of heavy metals arsenic, cadmium, lead and mercury and trace elements chromium, copper, nickel and zinc were tested in the muscle tissue of four commercial edible lethrinids fish species from different region of Mauritius. Sky emperor (Lethrinus mahsena) was collected from coastal regions as well as offshore regions (banks) for this study. Blackspot emperor (Lethrinus harak) and spangled emperor (Lethrinus nebulosus) were also studied for their popularity in the fish market. Condition factor was calculated for each fish and the highest value obtained was in Lethrinus mahsena collected from offshore regions $(2.598 \mathrm{~cm} / \mathrm{g})$. Flame atomic absorption spectrometry was used to analyse copper, nickel and zinc while, graphite furnace technique was used for cadmium, chromium and lead. Mercury levels were evaluated with the cold vapour technique and arsenic with the thermal hydride cell. The level of lead, mercury, copper, nickel and zinc ranged from 0.0011 $0.0024 \mathrm{mg} / \mathrm{L}, 0.0016-0.0036 \mathrm{mg} / \mathrm{L}, 0.080$ $0.389 \mathrm{mg} / \mathrm{L}, 0.566-1.192 \mathrm{mg} / \mathrm{L}$ and 0.219 0.422 respectively in wet weight. Interspecies variations in levels of heavy metals and trace elements were observed for nickel and no significant variations occurred for mercury, lead and zinc. Concentrations of heavy metals and trace elements were all within the permissible level except for nickel. As per this study, the Food Act 1998 of Mauritius must be reviewed in order to incorporate the Maximum Permissible Level for nickel.
\end{abstract}

\section{Introduction}

Increased heavy metal levels in the aquatic environment is attributed to human activities such as domestic effluents, agricultural runoff, offshore oil and gas explo- ration, industrials (paints, fertilisers, pesticides, textile, leather and pharmaceuticals) and mine drainage (Ansari et al., 2004). Erosion, volcanism and magmatic activity is said to cause atmospheric metal pollution responsible for dissolved metals such as arsenic (As), cadmium $(\mathrm{Cd})$, copper $(\mathrm{Cu})$, Iron (Fe), Nickel (Ni) and Zinc (Zn) to be present in the oceans (Chiarelli and Roccheri, 2014). Rise in the level of heavy metals in the marine environment has caused severe problem to the marine organism and humans (Bashir et al., 2013). Due to their capability to bio-accumulate heavy metals, edible fishes have gained serious concern and importance as the consumption of wild and aqua-cultured fish increased (Elnabris et al., 2012). Arsenic, cadmium , mercury $(\mathrm{Hg})$ and lead $(\mathrm{Pb})$ are categorised as harmful substances whereas chromium (Cr), copper, nickel and zinc are said to be beneficial to the human body system (Duffus, 2002; Duruibe et al., 2007). Lead is susceptible to children as it affects the developing nervous system due to rapid growth and metabolism. In addition, accumulation of cadmium in the human body has negative effects on several organs such as kidney, lungs, brain and kidney. Mercury is considered most toxic and ingestion in high concentrations affect developing fetus. However, if the concentration of trace elements such as copper is present in high concentration, this can cause adverse effects such as chronic anemia. Similar studies had been done in scombrids in Mauritius (Bhoyroo et al., 2015) and results showed levels of trace elements and heavy metals within permitted threshold levels for safe consumption, whereas threshold for Chromium level was not listed in Food Act 1998 of Mauritius.

Lethrinidae fish are widely consumed and are considered among the favourite dish of Mauritian. The Food and Agricultural Organisation (FAO) International Standard Statistical Classification for Aquatic Animals and Plants (ISSCAAP) has represented Lethrinidae fish family as demersal fishes and classified them as bottom-feeding (bottom-dweling) carnivorous fish. Due to their feeding habits and long life (30 years), Lethrinids can be used as an indicator of heavy metal bioaccumulation in the aquatic environment since they feed on mainly molluscs, crustaceans, sea urchins, hard-shell invertebrates and sometimes fishes (Carpenter and Allen, 1989). Increase in population together with increase in industrialization, have resulted in an increase in pollution to the marine environment and are causing potential risk for the marine organism and human health (Matoka et al., 2014). Mauritius, being a
Correspondence: Bhoyroo Vishwakalyan, Department of Food Sciences, Faculty of Agriculture, University of Mauritius, Reduit, Mauritius.

Tel: +230 57978038

Email: email: v.bhoyroo@uom.ac.mu

Acknowledgements: we are thankful to Mrs M. Seetohul, Mrs M. Budhoo, Miss F. Jaumdally, Mrs K.P. Ghoorbin, Miss B. Sohun, Mr S. Bundhun, Mr A. Soomaroo, Mr A. Jhurrea, Mrs I.A Noormohamed, Mrs A.Sobhee, Mr P.S Baboololl and Mr L Junye for their support for laboratory analysis. We are indebted to $\mathrm{Mr} \mathrm{V}$. Ramsahye and $\mathrm{Mr}$ C.D.W Abdool from the Faculty of Science, Chemistry Department (UoM) for their help and assistance with laboratory equipments.

Key words: Heavy metals, Lead, Mercury, Nickel, Lethrinids.

Received for publication: 1 February 2017. Revision received: 7 October 2017.

Accepted for publication: 10 October 2017.

This work is licensed under a Creative Commons Attribution-NonCommercial 4.0 International License (CC BY-NC 4.0).

(C) Copyright B. Saulick et al., 2017

Licensee PAGEPress, Italy

Italian Journal of Food Safety 2017; 6:6607

doi:10.4081/ijfs.2017.6607

small island is experiencing rapid growth in industry, tourism and population with consequent increase in production of more waste and the release of untreated sewage to the marine environment. The suggested Maximum Permissible Level (MPL) for heavy metals in the human diet as a safety regulation by international and national agencies such as the World Health Organisation (WHO), the Joint FAO/WHO Expert Committee on Food Additives (JECFA), the Ministry of Agro-industry and Food Security (MAIFS) together with the Mauritian Food Act 1998 are set to identify the concentration of heavy metals in foods. The Fulton's condition factor is used to calculate the relationship between the length and the weight of the fish in order to estimate the condition and feeding intensity of the fish (Ighwela et al., 2011).

The length and weight relationship is important in fisheries biology to assess the relationship between the weight and length and to find potential variances between different stocks of the same species (Ighwela et al., 2011). Moreover, the condition factor provides information about the feeding behaviour and growth rate, and is affected by the physiology and stage of growth of a fish (Da Coasta and Araújo, 2003; 
Vasantharajan et al., 2013). The assumption made to assess the condition factor of a fish is that heavier the fish of a particular length, the better the condition factor (Froese, 2006). Barnham and Baxter (1998) have adopted a standard to classify the condition factor of salmon. The condition factor $(\mathrm{k})$ was used to predict the health status and to estimate the feeding intensity of the fish (Abowei, 2010; Jin et al., 2015).

\section{Materials and Methods}

Selected fish species (Figure 1) were sampled from local markets and fishermen. The mass of the fishes $(\mathrm{g})$ was recorded in an electronic balance and the lengths $(\mathrm{cm})$ were determined using a fish board before dissection. The condition factor $(\mathrm{k})$ was calculated using the following equation:

$\mathrm{k}=($ weight in grams $) * 100 /($ length in $\mathrm{cm}) 3$

$100 \mathrm{~g}$ muscle tissues from each fish, mainly the mid dorsal muscle was cut into pieces and placed in a polyethylene bag for further analysis in the laboratory. Stomach and part of the intestine were dissected to study the feeding content of each species. All equipment used was cleaned properly and acid washed before reuse to prevent contamination. One hundred $g$ of each species were dried separately in an oven (CARBOLITE) at $70^{\circ} \mathrm{C}$ till constant weights were attained. Each dried sample was blended in an electric blender and for rapid and effective ashing. Then, $10 \mathrm{~g}$ of each blended sample was placed in a $50 \mathrm{~mL}$ crucible, labeled clearly with a heat resistant steel ball paint marker and were transferred in a muffle furnace (CARBOLITE S302RR) and ashed at $450^{\circ} \mathrm{C}$ for 8 hours (García-Montelongo et al., 1994). After 8 hours, each crucible was removed and $2 \mathrm{~mL}$ of $\mathrm{HNO}_{3}$ was added to the sample, allowed to evaporate to dryness in a sand bath and transferred again into the muffle furnace to obtain carbon free solution (Perkin-Elmer, 1996). Once the crucible was cooled at room temperature, the white ash was treated with $5 \mathrm{ml} \mathrm{HNO}_{3}$ in a sand bath at $60^{\circ} \mathrm{C}$, filtered with ashless filter papers to eliminate any un-dissolved residues and volume made up to $25 \mathrm{~mL}$ with distilled water. Samples were then transferred in plastic bottles of $50 \mathrm{~mL}$ and placed into the refrigerator at $4^{\circ} \mathrm{C}$ for further analysis. The element selected was analysed using different techniques of AAS as suggested by Olowu et al. (2009).

\section{Detection of metal through flame atomic absorption spectroscopy}

Flame spectroscopy is an analytical technique used for the qualitative and quantitative determination on an element that uses thermal energy in the form of flame to excite free atoms to higher energy levels (Nick, 1995). The metals detected using the flame emission spectroscopy are cadmium, chromium, copper, lead, nickel and zinc. However, it must be noted that cadmium, chromium and lead was not detected when using flame spectroscopy and hence the graphite furnace technique was used. The working range was from $1 \mathrm{ppm}$ to $5 \mathrm{ppm}$ on heavy metals in fish in the marine environ-

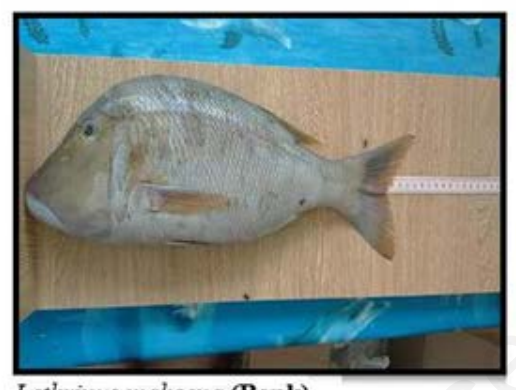

Lethrinus mahsena (Bank)

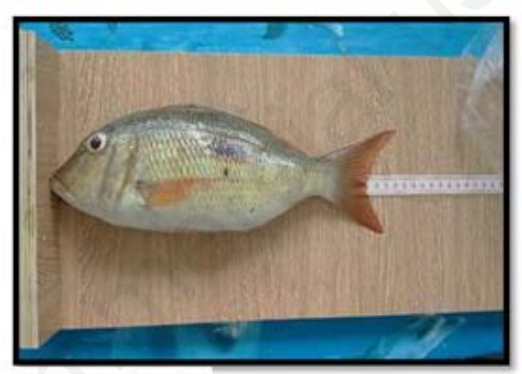

Lethrinus harak ment. Standard solutions were prepared in parts per million. Metals such as cadmium, chromium, copper and lead were further analysed using the graphite atomic absorption spectrophotometer. The standard solution was prepared in parts per billion and the working range was from $1 \mathrm{ppb}$ to $5 \mathrm{ppb}$.

\section{Detection of arsenic and mercury through hydride atomic absorption spectroscopy}

Hydride atomic absorption spectroscopy system is a continuous flow of

Figure 1. Plates showing the four fish species being studied for heavy metal and trace elements bioaccumulation.

Table 1. Condition factor of fish sampled.

\begin{tabular}{lcc}
\hline Fish species & Summer & Winter \\
\hline Lethrinus mahsena Bank & 0.999 & 2.598 \\
Lethrinus mahsena Coastal & 1.881 & 2.023 \\
\hline Lethrinus harak & 1.488 & 1.121 \\
Lethrinus nebulosus & 1.321 & 0.812 \\
\hline Lethrinus mahsena Bank & 1.627 & 1.06 \\
Lethrinus mahsena Coastal & 1.662 & 1.444 \\
\hline Lethrinus harak & 1.424 & 2.285 \\
Lethrinus nebulosus & 1.226 & 1.46 \\
\hline Lethrinus mahsena Bank & 1.561 & 1.761 \\
Lethrinus mahsena Coastal & 1.558 & 1.438 \\
\hline Lethrinus harak & 1.453 & 1.564 \\
Lethrinus nebulosus & 1.19 & 1.674
\end{tabular}

$\mathrm{K}$, condition factor. The condition factor of the fish ranged from $1.0 \mathrm{~cm} / \mathrm{g}$ to $2.6 \mathrm{~cm} / \mathrm{g}$. Only for Lethrinus mahsena (Bank) in summer and Lethrinus nebulosus in winter, the condition factor was below $1(0.999 \mathrm{~cm} / \mathrm{g}$ and $0.812 \mathrm{~cm} / \mathrm{g}$ respectively.

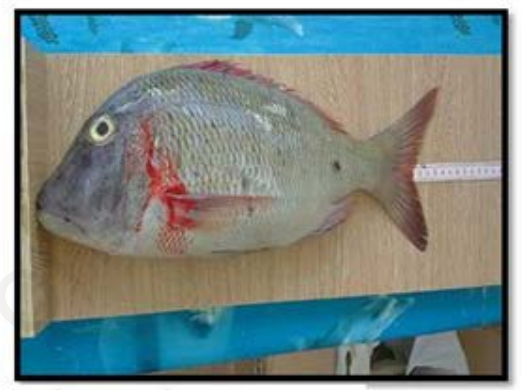

Lethrinus mahsena (Coastal)

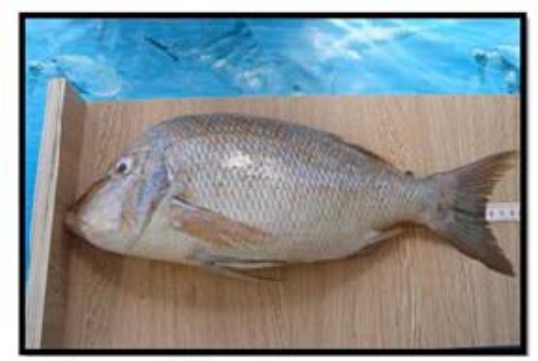

Lethrinus nebulosus 
vapour generation system that increases the sensitivity of the atomic absorption technique for mercury and hydride forming metals such as arsenic. Sodium borohydride $\left(\mathrm{NaBH}_{4}\right)$ operation was used instead of the stannous chloride $\left(\mathrm{SnCl}_{2}\right)$ and the operation involved reaction of the analyte in an acidified solution with $\mathrm{NaBH}_{4}$ to form gaseous hydride. Arsenic was detected using the thermal hydride cell system and mercury was detected using the cold vapour technique. The standard solution was prepared according to the working standard ranging from $1 \mathrm{ppb}$ to $5 \mathrm{ppb}$.

\section{Results and Discussion}

Analysis of heavy metals such as As, $\mathrm{Cd}, \mathrm{Hg}, \mathrm{Pb}$ and trace elements such as $\mathrm{Cr}$, $\mathrm{Cu}, \mathrm{Ni}$, and $\mathrm{Zn}$ through the atomic absorption spectrometer in muscle tissue of the four fish species namely the sky emperor (Lethrinus mahsena, Bank), sky emperor (Lethrinus mahsena, coastal), blackspot emperor (Lethrinus harak) and the spangled emperor (Lethrinus nebulosus) in different region of Mauritius, confirmed the presence of trace elements primarily of $\mathrm{Cu}, \mathrm{Ni}$ and $\mathrm{Zn}$ and heavy metals $\mathrm{Hg}$ and $\mathrm{Pb}$. The bioaccumulation of heavy metals and trace elements in muscle of fish is mainly related to 1) feeding habits, 2) the rate at which the organism metabolise the metals and 3) the surrounding water condition (Asante et al., 2014). Other factors to consider include environmental factors such as salinity, hardness, temperature, $\mathrm{pH}$, water and basic factor such as age of the fish (Akan et al., 2012;). The condition factor, K, provides information on the growth rate and the feeding behaviour of the fish and a value greater than $1 \mathrm{~cm} / \mathrm{g}$ point to well being and robustness of the fish (Vasantharajan et al., 2013). Fish sampled were in good condition (Table 1) with $\mathrm{K}$-value greater than $1.4 \mathrm{~cm} / \mathrm{g}$ and only two fish species had $\mathrm{K}$ value less than $1.0 \mathrm{~cm} / \mathrm{g}$ and were classified as poor fish (Barnham and Baxter, 1998). Thus fish taken for this study were healthy and had a proper feeding behaviour and faced ideal environmental condition, which justify for the bioaccumulation of trace elements and heavy metals in the muscle tissue of the fish. Moreover, three fish species: Lethrinus mahsena Bank, Lethrinus mahsena Coastal and Lethrinus harak had condition factors greater than $2.0 \mathrm{~cm} / \mathrm{g}(2.598 \mathrm{~cm} / \mathrm{g}, 2.023$ $\mathrm{cm} / \mathrm{g}$ and $2.285 \mathrm{~cm} / \mathrm{g}$ ) which can account for their feeding behaviours and rapid growth rates. The feeding habit of the lethrinids is attributed to the accumulation of arsenic and cadmium. Lethrinidae fish consume crustacean, mollusc, fish and shellfish (King and Fraser, 2002; Addison and Tindall, 1990). CODEX STAN 1931995 (2009) confirmed the presence of arsenic and cadmium in crustaceans, fish, mollusc and shellfish (Table 2). Positive correlations were obtained between fork length and heavy metal concentrations; and similarly fresh weight and heavy metal bioaccumulation showed positive co-relation for most heavy metals except zinc (Table 3 ).

The level of zinc $(\mathrm{P}=0.884)$, lead $(\mathrm{P}=0.254)$ and mercury $(\mathrm{P}=0.290)$ accumulated in the muscle tissues were not significantly different $(\mathrm{P}>0.005)$ among the four fish species. The highest concentration of Zinc $\quad(0.496 \pm 0.198 \quad \mathrm{mg} / \mathrm{kg}), \quad$ lead $(2.804 \pm 1.030 \mu \mathrm{g} / \mathrm{kg})$ and mercury $(4.228 \pm 1.012 \mu \mathrm{g} / \mathrm{kg})$ were all recorded in Lethrinus nebulosus, and lowest in Lethrinus mahsena Bank for zinc $(0.259 \pm 0.024 \mathrm{mg} / \mathrm{kg})$, Lethrinus mahsena Coastal for lead $(1.313 \pm 0.402 \mu \mathrm{g} / \mathrm{kg})$ and Lethrinus harak for mercury $(1.942 \pm 1.776$ $\mu \mathrm{g} / \mathrm{kg}$ ) (Figure 2).

Uptake of heavy metals and trace elements is related to fish age, mass and length and aquatic environment. This clearly supports the fact that higher concentration of

Table 2. Levels of heavy metals in the different Lethrinus species.

\begin{tabular}{lllcccc} 
Species & & N & Minimum & Maximum & Mean & SD \\
Lethrinus mahsena (bank) & Copper & 6 & .07 & .50 & .2408 & .17375 \\
& Zinc & 6 & .21 & .65 & .3403 & .16475 \\
& Nickel & 6 & .98 & 1.60 & 1.2367 & .26126 \\
& Mercury & 6 & .98 & 4.00 & 2.8730 & 1.12229 \\
& Lead & 6 & 2.05 & 3.15 & 2.3918 & .40361 \\
Lethrinus mahsena (coastal) & Copper & 6 & .10 & .49 & .2395 & .16164 \\
& Zinc & 6 & .05 & .57 & .3620 & .19832 \\
& Nickel & 6 & .71 & 1.40 & 1.0205 & .27297 \\
& Mercury & 6 & .79 & 4.37 & 3.3617 & 1.35339 \\
& Lead & 6 & .78 & 2.42 & 1.5855 & .68566 \\
\hline Lethrinus harak & Copper & 6 & .08 & .39 & .2030 & .13130 \\
& Zinc & 6 & .01 & .55 & .3682 & .20401 \\
& Nickel & 6 & .55 & 1.14 & .8672 & .24819 \\
& Mercury & 6 & .12 & 4.35 & 2.2118 & 1.44368 \\
& Lead & 6 & .72 & 3.48 & 2.0262 & .92427 \\
Lethrinus nebulosus & Copper & 6 & .08 & .77 & .3895 & .25981 \\
& Zinc & 6 & .22 & .65 & .4273 & .17693 \\
& Nickel & 6 & .87 & 1.96 & 1.3877 & .39559 \\
& Mercury & 6 & 2.57 & 5.15 & 3.5968 & 1.07054 \\
& Lead & 6 & 1.66 & 4.26 & 2.4912 & .96763 \\
\hline
\end{tabular}

SD, standard deviation.

Table 3. Correlation between size and heavy metal concentrations.

\begin{tabular}{llcccccc}
\multirow{3}{*}{ Fork length } & & Mercury & Copper & Lead & Nickel & Zinc \\
& & Pearson correlation & .298 & $.543^{* *}$ & .357 & $.441^{*}$ & .106 \\
& Significance (2-tailed) & .157 & .006 & .086 & .031 & .624 \\
\multirow{5}{*}{ Fresh weight } & Pearson correlation & .320 & $.424^{*}$ & .284 & .191 & -.120 \\
& Significance (2-tailed) & .128 & .039 & .178 & .371 & .575 \\
& $\mathrm{~N}$ & 24 & 24 & 24 & 24 & 24 \\
\hline
\end{tabular}

${ }^{*}$ Correlation is significant at the 0.05 level (2-tailed); ${ }^{* *}$ correlation is significant at the 0.01 level (2-tailed) zinc, lead and mercury were recorded in Lethrinus nebulosus and lowest concentration of lead in Lethrinus mahsena Coastal. Kumar et al. (2013) also supported the fact that there are significant differences een species and heavy metals accumufish. Differences in the heavy species in different regions can be attributed to associated environmental factors.

In Mauritius, the Maximum Permisible level (MPL) of heavy in fish and foodstuff is regulated by the Food Act 1998. agencies such as the Joint FAO/WHO Expert Committee on Food Additives (JECFA), the European Union EU), the Ministry of Agriculture, Fisheries (MAFF) in Britain and the CODEX Alimentarius Commission (2011) have set regulation on heavy metals and trace element in the human diet for security Each international guideline can be compared with the Mauritian Food Act 1998 as a result of differences in threshold of heavy metals.

A copper is a widely used element worldwide and is responsible for the development of bones in the human 
body but can have negative effect if the MPL is exceeded. The Mauritian Food Act has stated a tolerable level of copper of 30 $\mathrm{mg} / \mathrm{k}$ (ppm), MAFF (1995) $20 \mathrm{mg} / \mathrm{kg}$ wet weight and the Provisional Tolerable Daily Intake set by the CODEX 135- 1995 ranges from $0.05 \mathrm{mg} / \mathrm{kg}$ to $0.5 \mathrm{mg} / \mathrm{kg}$. The concentration of copper obtained in wet weight for copper ranged from $0.265 \mathrm{mg} / \mathrm{kg}$ to 0.389 $\mathrm{mg} / \mathrm{kg}$ in summer and $0.079 \mathrm{mg} / \mathrm{kg}$ to 0.273 $\mathrm{mg} / \mathrm{kg}$ in winter. As a result, the concentration of copper generated during the two seasons did not exceed the threshold level for International and local agencies and is near the level set by the CODEX 135- 1995 for the daily intake of copper.

Furthermore, zinc is an important element needed in very minute amount in the human body but again if the level of the metal is exceeded, this can lead to severe health effect. Taking into consideration the Food Act settle in Mauritius, the tolerable level of zinc accepted in food stuff is at 100 $\mathrm{mg} / \mathrm{kg}(\mathrm{ppm})$ and for MAFF (1995) is at 50 $\mathrm{mg} / \mathrm{kg}$. Other agencies such as the CODEX 135- 1995 has set a Provisional Tolerable Daily Intake for zinc at $0.3 \mathrm{mg} / \mathrm{kg}$ to 1.0 $\mathrm{mg} / \mathrm{kg}$. Hence, the result obtained during summer and winter ranged from 0.219 $\mathrm{mg} / \mathrm{kg}$ to $0.422 \mathrm{mg} / \mathrm{kg}$ wet weight of zinc. Hence, it can be concluded that fish sampled were safe for consumption and according to the value set up by the CODEX 1351995 , it was safe to consume daily.

Moreover, the concentration of mercury detected was expressed in $\mu \mathrm{g} / \mathrm{kg}(\mathrm{ppb})$ and then was converted to $\mathrm{mg} / \mathrm{kg}(\mathrm{ppm})$. The level of mercury detected for the four fish species ranged between $0.0016 \mu \mathrm{g} / \mathrm{kg}$ to $0.0036 \mu \mathrm{g} / \mathrm{kg}$ wet weight. According to the Mauritian Food Act 1998, the acceptable level of mercury in fish is set at $1.0 \mathrm{mg} / \mathrm{kg}$ (ppm). According to the CODEX 1351995, the provisional tolerable weekly intake for mercury is at $0.005 \mathrm{mg} / \mathrm{kg}$. Therefore, since the four fish species have level of mercury within the range, it can be deduced that the fish is well safe in the human diet. Likewise, the tolerable concentration of lead is at $2.0 \mathrm{mg} / \mathrm{kg}(\mathrm{ppm})$. Besides, the threshold level of lead set up by the WHO (1989) is also at $2.0 \mathrm{mg} / \mathrm{kg}$ (ppm) and the CODEX 135- 1995, the provisional tolerable weekly intake for lead is at $0.025 \mathrm{mg} / \mathrm{kg}$. The concentration of Lead detected was expressed in $\mu \mathrm{g} / \mathrm{kg}$ (ppb) and

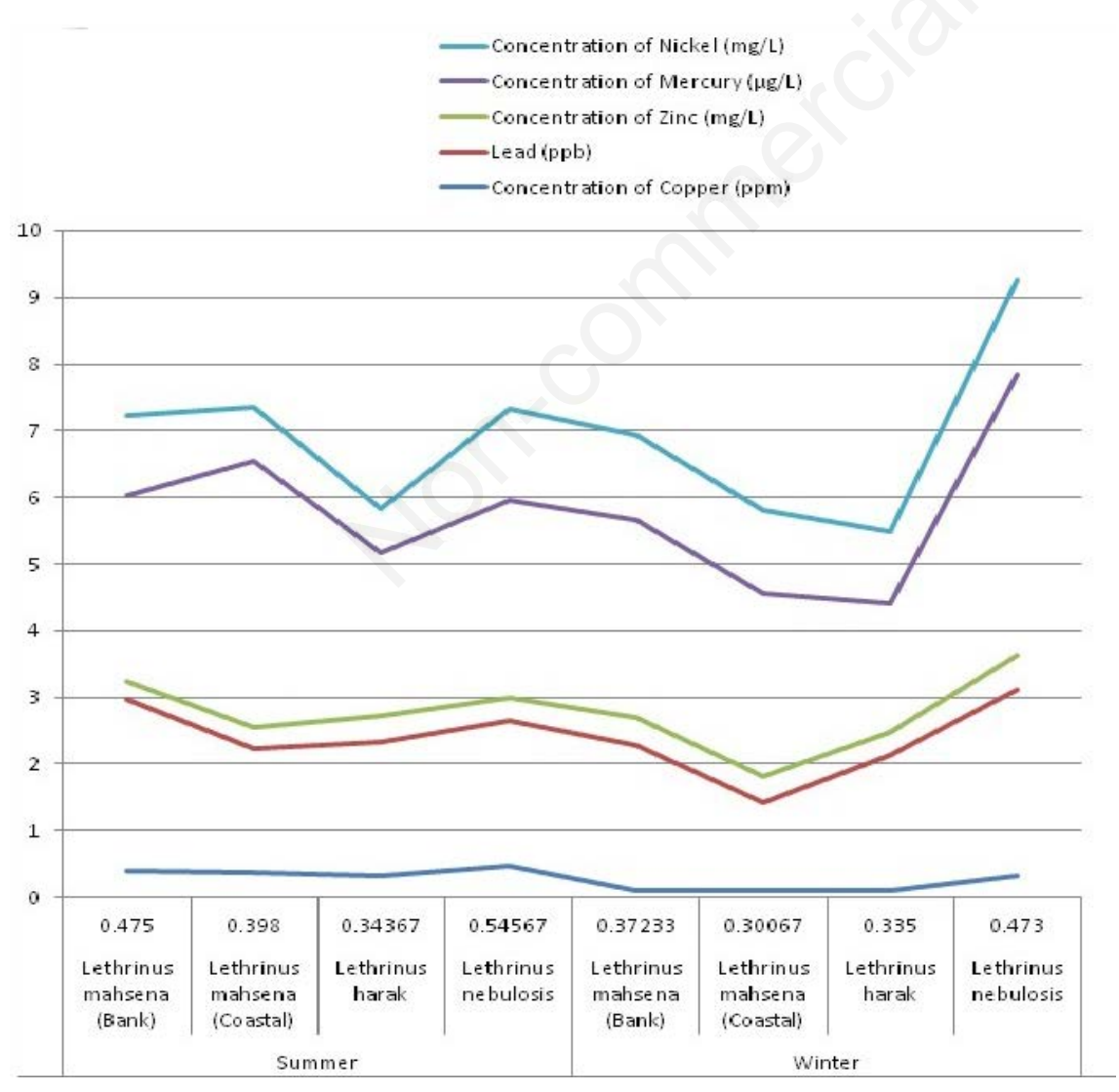

Figure 2. Chart showing the average levels of heavy metals and trace elements recorded in the four different species of Lethrinids. Peaks in heavy metal concentration are associated to increased size of the fish specimen. Lethrinus nebulosis is the largest among the four species. then was converted to $\mathrm{mg} / \mathrm{kg}$ (ppm). Lead concentrations in this study ranged from $0.0011 \mu \mathrm{g} / \mathrm{kg}$ to $0.0024 \mu \mathrm{g} / \mathrm{kg}$ wet weight, well below the limits. The leading area of concern for this study is nickel since the level obtained for this study is quite high. The Mauritian food act 1998 and the CODEX 135-1995 have no MPL set for nickel but conferring to the WHO (1989), the MPL set for the metal ranged from 0.5 $\mathrm{mg} / \mathrm{kg}$ to $1.0 \mathrm{mg} / \mathrm{kg}$ wet weight in muscle tissue of fish. Henceforth, the result obtained for this study showed $0.676 \mathrm{mg} / \mathrm{kg}$ to $1.192 \mathrm{mg} / \mathrm{kg}$ which clearly indicate that the fish taken for the research is close to the threshold set by WHO (1989). The Food Act should be amended to consider the thresholds for Nickel.

\section{Conclusions}

This study highlights the importance of heavy metal bio-accumulation, shows a positive co-relation between size and heavy metal accumulation but also suggests that The Mauritian Food Act should be amended to consider thresholds for Nickel even though it is not considered a highly toxic metal and does not cross the threshold set by WHO.

\section{References}

Abowei JFN, 2010. The condition factor, length-weight relationship and abundance of Ilisha Africana (Block, 1795) from Nkoro River Niger Delta, Nigeria. Adv J Food Sci Technol 2:6-11.

Addison B, Tindall J, 1990. Underwater Guide to coral Fishes of the Indian Ocean. Southern Book Publishers (Pty) Ltd.

Akan J, Mohmoud S, Yikala B, Ogugbuaja $\mathrm{V}$, 2012. Bioaccumulation of Some Heavy Metals in Fish Samples from River Benue in Vinikilang, Adamawa State, Nigeria. Am J Anal Chem 3:72736.

Ansari TN, Mar IL, Tariq N, 2004. Heavy metals in marine pollution perspective. A mini review. J Appl Sci 4:1-20.

Asante F, Agbeko E, Addae G, Quainoo AK, 2014. Bioaccumulation of Heavy Metals in Water, Sediments and Tissues of Some Selected Fishes from the Red Volta, Nangodi in the Upper East Region of Ghana. BJAST 4:594-603.

Barnham C, Baxter A, 1998. Condition factor $\mathrm{K}$ for salmonid fish. Available from: http://bamboorods.ca/Trout $\% 20$ condition $\% 20$ factor.pdf 
Bashir FH, Othman MS, Mazlan AG, Rahim SM, Simon KD, 2013. Heavy metal concentration in fishes from the coastal waters of Kapar and Mersing, Malaysia. Turk J Fish Aquat Sci 13:375-82.

Bhoyroo V, Soobratty N, Lalljee B, 2015. Detection of heavy metals bio-accumulation in scombrids for the determination of possible health hazard. J Food Sci Tech 6:98-107.

Carpenter KC, Allen GR, 1989. Emperor Fishes and large-eye breams of the world (family Lethrinidae). An annoatated and illustrated catalogue of lethrinid species known to date. FAO, Rome, Italy.

Chiarelli R, Roccheri MC, 2014. marine invertebrates as bioindicators of heavy metal pollution. O J Metal 4:93-106.

Codex Alimentarius Commission, 2011. Joint FAO/WHO Food Standards Programme Codex Committee on Contaminants in Foods. Working Document for Information and Use in Discussions Related to Contaminants and Toxins in the GSCTFF. Fifth Session. Prepared by Japan and Netherlands. Available from: www.fao. org/input/download/report/758/REP11 CFe.pdf

Codex Standard, 2009. Codex General Standard for Contaminants and Toxins in Food and Feed. Codex Stan 1931995.

Da Costa MR, Araujo FG, 2003. Lengthweight relationship and condition factor of Micropogonias furnieri (Desmarest) (Perciformes, Sciaenidae) In the Sepetiba Bay, Rio de Janeiro State, Brazil. Rev Bras Zool 20:685-90.

Duffus JH, 2002. Heavy Metals. A meaningless term? Pure Appl Chem 74:793807.
Duruibe JO, Ogwuegbu MOC, Egwurugwu, JN, 2007. heavy metal pollution and human biotoxic effects. Int J Phys Sci 2:112-8.

Elnabris Kj, Muzyed SK, EL-Ashgar NM, 2012. Heavy metal concentrations in some commercially important fishes and their contribution to heavy metals exposure in Palestinian people of Gaza Strip (Palestine). J Assoc Arab Univ Basic Appl Sci 13:44-51.

Food Act, 1998. Food Act, Ministry of Health and Quality of Life, Mauritius.

Froese R, 2006. Cube law, condition factor and weight-length relationships: history, meta- analysis and recommendations. J Appl Ichthyol 22:241-53.

Garcia-Montelongo F, Díaz C, Galindo L, Larrechi MS, Rius X, 1994. Heavy metals in three fish species from the coastal waters of Santa Cruz de Tenerife (Canary Island). Sci Mar 58:179-83.

Ighwela KA, Ahmed AB, Abol-Munafi AB, 2011. Condition factor as an indicator of growth and feeding intensity of Nile Tilapia fingerlings (Oreochromis niloticus) feed on different levels of maltose. Am-Euras J Agric Environ Sci 11:55963.

Jin S, Yan X, Zhang H, Fan W, 2015. Weight- length relationships and Fulton's condition factors of skipjack tuna (Katsuwonus pelamis) in the Western and central Pacific Ocean. Peer J 3:758.

King D, Fraser V, 2002. More Reef Fishes \& Nudibranch: East and \& South Coast of Southern Africa. Struik Publishers (Pty) Ltd, Cape Town, South Africa.

Kumar SC, Jaikumar M, Robin RS, Karthikeyan C, Kumar S, 2013. Heavy Metal Concentration of Sea Water and Marine Organisms in Ennore Creek, Southeast Coast of India. J Toxicol
Health Photon 103:192-201.

MAFF, 1995. Monitoring and surveillance of non-radioactive contaminants in the aquatic environment and activities regulating the disposal of waste at sea, 1993. Aquatic Environment Monitoring Report No. 44. Technical Report. Directorate of Fisheries Research, Lowestoft, UK.

Matoka CM, Omolo SO, Odalo JO, 2014. Heavy metal bioaccumulation as indicators of environmental pollution and health risks. J Env Sci Toxicol Food Tech 8:24-31.

Nick A, 1995. Flame Methods Manual for Atomic Absorption, AA Hydride System HG 3000, EHG 3000 \& MC 3000. GBC Scientific Equipment PTY LTD, Braeside, Australia.

Olowu RA, Ayeju OO, Adewuyi GO, Adejoro IA, Denloye AA, Babatunde AO, Ogundajo AL, 2009. Determination of Heavy metals in Fish Tissues, Water and Sediment from Epe and Badagry Lagoons, Lagos, Nigeria. Eur J Chem 7:215-21.

Perkin-Elmer, 1996. Analytical Methods for Atomic Absorption Spectroscopy. FP-5Analysis of Fish and Seafood: Dry Ashing Procedure. Perkin-Elmer, Waltham, MA, USA.

Vasantharajan M, Jawahar P, Sundaramoorthy B, Venkatasamy M, 2014. Length-weight relationship of Lethrinus lentjan (La Cepede, 1802) and Lethrinus nebulosus (Forsskal, 1775) exploited in Thoothukudi Coast, Tamil Nadu, India. Int J Vet Anim Sci Res 43:14-8.

WHO, 1989. Heavy metals-environmental aspects. Environment Health Criteria. No. 85. WHO, Geneva, Switzerland. 